\title{
THE VICUÑNA
}

\section{By G. Dennler de la Tour, M.D., D.Sc.}

In form the vicuña resembles the guanaco, but it is smaller and slenderer. Its colour is not easy to describe and in South America people simply refer to "vicuña colour" which varies from pale fawn, through vermilion and golden to strongly fulvous. The vicuña has no black on its face as has the guanaco. From the throat to the knees there is a pure white tuft, the belly and inner sides of the limbs are white also. The vicuna stands from 28 to 35 inches $(70$ to $90 \mathrm{~cm}$.) high at the shoulder, its average size decreasing from south to north. Its wool is shorter but much finer than that of the guanaco and is probably the finest and lightest wool in the world.

The Problem of Sub-species.-Molina, who first described the vicuña, named it Camelus vicugna, which was later changed to Lama vicugna and, by Miller (1924), to Vicugna vicugna. Thomas, in 1917, separated a sub-species Lama vicugna mensalis, basing his description on specimens from Incaparra, near Junin, Peru, while Molina's description was based on the vicuña of northern Chile. Exact delimitation between the original southern Lama vicugna vicugna and the northern race, L.v. mensalis was never given.

It seems most unlikely to me that if bigger series from different zones were to be examined morphological differences between the two forms would be found which could justify their separation into two sub-species. Size and shades of colour between pale fawn (indicated for L.v. vicugna) and strongly fulvous (indicated for L.v. mensalis) vary individually along the whole habitat. This $I$ was able to prove by examining dozens of skins in many zones of Peru, Bolivia and Argentina, for I was unable to find any relation between a defined size or shade of colour and a determined region of the habitat.

There is also a gap in distribution indicated for the two geographic races : the range of L.v. mensalis is given as Peru and Bolivia, with a restriction in the latter to a " restricted area in the north-central part". "This would leave typical Vicugna vicugna as the form of Chile, where it is possibly now extinct" (Allen, l.c., p. 410). How are we to classify the vicuñas of the southern parts of Bolivia and the north-west of Argentina?

Habits.-Vicunas are found in small droves of five to fifteen females led by an adult male which watches over the flock. Young males are expelled from the flock by their mothers when they are eight to ten months old and unite into herds of from 
twenty to a hundred or more. When a drove of vicuñas senses danger, the animals run away downhill, never uphill as chamois do.

The mating season lies between April and June and as the gestation period is ten months, parturition occurs between January and March. The vicuña almost always produces one offspring only, which is called "vicuñita". In confinement it does not breed readily.

Vicuñas feed on grass of Poa, Bromus, Agrostis, Stipa, and other alpine genera. They drink only every two days and always use the same track to water. The Indian hunters take advantage of this habit for the vicuñas are easy to kill on their way back from water with their stomachs full.

When forced to live at low altitudes, vicuñas easily get parasitic infections, such as lungworm, scab and flukes.

Habitat and Distribution.--The vicuña, generally speaking, lives at higher altitudes than the guanaco. Its biotope lies in vast plains from 3,500 to 5,500 metres above the sea. It likes the steep slopes of the mountain tops, minding neither snow nor ice, and does not feel uneasy in glacial winds or snow-storms. It enjoys humid meadows which lie adjacent to the eternal snowsummits of the Andes, many of which reach and pass the 6,000 metre mark.

Vicuñas occur in the high plateaux of the Andes between $3^{\circ} \mathrm{S}$. and $30^{\circ} \mathrm{S}$. ; that is in the extreme south of Ecuador, in Peru and Bolivia, in the extreme north of Chile and in northwestern Argentina. Their southern limit is in Argentina at about the Agua Negra river, i.e. on the frontier between the provinces of San Juan and La Rioja, while their Chilean range does not go so far southwards, at least not to-day. But in the epoch of Molina, vicuñas occurred also in the Chilean provinces of Coquimbo and Copiapo. With that exception the species has not lost any part of its range as a whole. But where man has advanced with his sheep and his goats, his alpaca and lama breeding and his mining, the vicuña has receded to higher altitudes.

Decreasing Numbers.-The vicuña was plentiful throughout its range in the era of the Inca Imperium. Hunting was only allowed every four or five years under official control and only adult males were killed, the females sheared and freed. Under the Spanish colonial regime hunting was free and, according to reports, about $\mathbf{8 0 , 0 0 0}$ vicuñas were killed per year in Peru and northern Chile. After liberation from the Spaniards, the natives returned to the earlier practice of shearing and then 


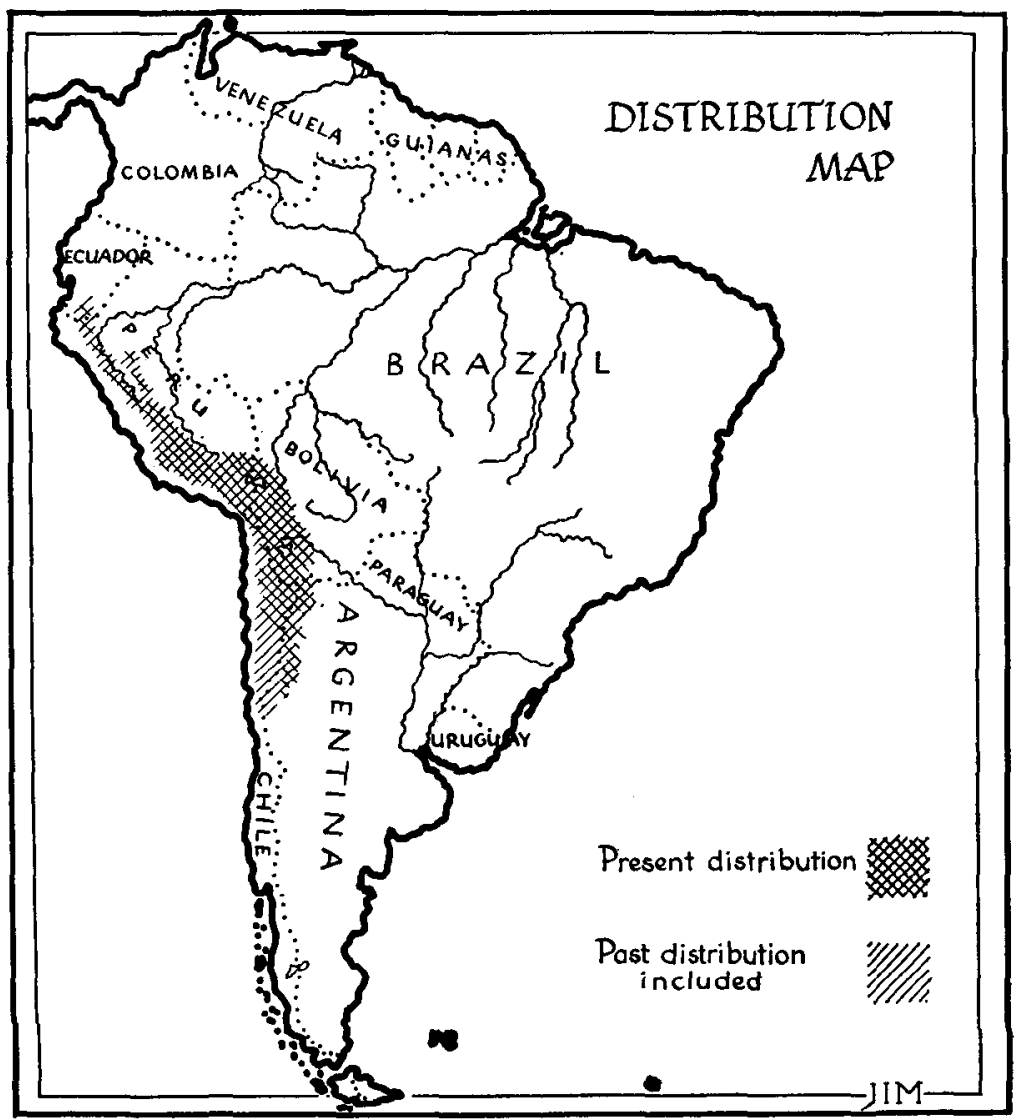

freeing the animals. Tschudi (1844) describes this as "chaco": "They carried out extensive drives, gradually working the animals into a narrow funnel-shaped place among the rock walls, where many were captured, their wool sheared and the captives then freed." After this pause the decline of the vicuña began again, for the export market demanded vicuñita skins, vicuña robes and vicuña wool. The use of firearms not only stopped the old "chacos" which saved the animals after shearing, but also destroyed whole flocks, for the hunters took advantage of the females' habit of remaining near the male after he was killed. Thus a whole drove could be slaughtered one after another. In this manner thousands were killed. The wool output of one vicuña gives an average of 500 grammes. The superstition that the bezoars (stomach-stones) have a 
medical and aphrodisiac value may also have contributed to the practice of killing the animals, instead of just shearing them.

Status.- It is difficult to estimate even approximately the number of vicuñas living to-day. In Peru the total number, in 1940, was calculated at nearly a million; the document (Pan Am. Union, vol. i, part 2, p. 30) reads : "It is hoped that with stricter hunting and breeding regulations the flocks will continue to increase gradually." Neither from Bolivia, Chile nor Ecuador has it ever been possible to get reliable data.

In Argentina the only census was in the year 1908, and indicated 8,000 vicuñas for the whole republic; but this figure cannot be correct because the same census gives 8,000 for the province of Salta; it merely means that the other provinces where vicuñas exist, Jujuy, Catamarca, La Rioja and the Territorio Nacional de los Andes, did not respond to the census questionnaire.

I have travelled much in vicuna country, but in spite of my own observations, information from other people and examination of skins, I cannot give a figure for the number of living vicuñas; but I cannot believe that its total reaches a million in all five countries, and I dare say it is not even half a million.

Protection.-The first protection measures go back to the Inca Imperium when, as already mentioned, hunting was allowed only every four or five years and then under the strictest control. Only the members of the Inca clan were allowed to wear clothes made of vicuña wool or use vicuña robes. The common people were compensated by the carcases of the killed vicuña males, and of deer and other game caught in the corral. After liberation from Spain, Bolivar himself by decree of 5th July, 1825, accorded protection to the vicuna. But the law soon became a dead letter. During the present century, Peru, 8th October, 1920, prohibited the sale of vicuña skins and the making of goods from its wool, and Bolivia prohibited the export of vicuña skins.

In Argentina a decree issued of 19th January, 1926, prohibited the hunting and exportation of vicuñas as well as the transportation and sale of their skin and fur. But hunting of vicuñas was authorized during the five years following the date of the decree, permits being issued by the police, open season from April to June. During the same season, by a decree issued on 9 th $\Lambda$ pril, 1934, Indians were permitted to capture vicunas in the Territorio Nacional de los Andes for domestication and establishment of nurseries. The law of hunting and fauna protection No. 13.908 of 25 th July, 1950, and its regulation by 
decree No. 15.501 of 20th August, 1953, does not refer to vicunas because the law is valid only in the National Territories, and vicuñas exist only in provinces Salta, Jujuy, Catamarca and La Rioja, which have their own legislation.

The efficiency of all measures issued in one country or another will always be disputable, as long as their enforcement is not based on international co-operation. The basis of co-operation is the co-ordination of the measures, a postulate on which I have always insisted. In a paper presented to the $\mathbf{X}^{\circ}$ Congreso Científico Chileno con Extensión Interamericana (1942), for example, I included the question of vicuña protection and said (see G.D.T., 1943, pp. 149-150) : "In Argentina and Peru hunting of the vicuña is prohibited; in Bolivia the exportation of vicuña-skins is not allowed, but hunting is not forbidden. Skins of vicuñas killed in Peru by poachers, once brought to Bolivia by smugglers, can be frecly purchased in that country. In Argentina the commerce of vicunas is allowed when the skins are marked as proceeding from Bolivia (really many of them have never seen Bolivia, but are poached in Argentina), without any consideration to the fact that exportation from Bolivia is prohibited."

Wild life protection is only efficient when based on international co-ordination and co-operation.

\section{BIBLIOGRAPHY}

Allen, Glover M., 1942. Extinct and Vanishing Mammals of the Western Hemisphere, Washington, pp. 409-412.

Cabrera, Angel, and Yepes, José, 1940. Mamíferos Sudamericanos. Buenos Aires, pp. 267-9.

Dennler DE LA Tour, Georges, 1941. La protección a la naturaleza en el Congreso Panamericano de Lima. Rev. Arg. Zoogeogr., Buenos Aires, vol. i, No. 2.

1943. Coordinación intersudamericana de las medidas de protección a la

fauna. Rev. Arg. Zoogeogr., vol. iii, No. 3, pp. 129-133.
1944. La protección a la fauna necesita acción y espíritu concordantes de todos los paises del continente. Diana, vol. vii, No. 56.

- 1949. Liste des animaux menacés ou en voie de disparition en Argentine. Rapport au Congrès de Lake Success, UIPN and UNESCO.

1952. La preservación de la fauna en región semi-árida. Parte VII a. La Puna de Atacama y la Pampa de Tamarugal. Diana, No. 155.

1952. Préservation de la faune dans les zones semi-arides des Cordilères des Andes chiliennes-argentines. En collab, avec Mr. C. A. Finsterbusch. Congrès de Caracas de l'UIPN. Rapport 20.

Gutierrez Madueño, C., 1912. Monografía de la vicuña. Lima : IV Congreso Cientifico Panam.

Holmberg, Eduardo A., 1901. La vicuña. An. Soc. Rur. Arg., vol. 36.

Lydekrer, Richard, 1915. Catalogue of the Ungulate Mammals, vol. 4 Camelidae.

Maccagno, Luis, 1932. Los Auquénidos Peruanos. Lima.

Motrna, J. Ignacio, 1782. Saggio sulle storia naturale del Chile, pp. 313-18. 
Oviedo y Valdes, Capitan Gonzalo Fernandez de, 1535. II istoria General y Natural de Indias, Libro XII, Cap. XXX, p. 418.

Pan Amenican Union, 1940. Documentary Material on Nature Protection and Wild Life Preservation in Latin America, vol. i, part 2. Washington.

Romero, Elias C., 1927. Llamas y Alpacas, Vicuñas y Guanacos. Buenos Aires.

Thomas, Oldfield, 1917. Smithsonian Misc. Coll., vol. 68, No. 4.

Tschudi, Johann Jacob von, 1844. Fauna Peruana.

Note.-This is Dr. de La Tour's second contribution on the status and preservation of South American mammals. "The Guanaco" appeared in Oryx, volume 2, No. 5.

\title{
NATIONAL PARKS-THE CITIZEN'S RESPONSIBILITY
}

\author{
By Fred M. PACKard \\ (Executive Secretary, National Parks Association of the United \\ States of America.)
}

America's magnificent system of national parks and monuments is a tribute to one of the salient characteristics of the American people - a consciousness of civic responsibility to each other. In a culture often accused of being dollar-mad, some twenty-four million acres of the finest primeval land available has been reserved at the insistence of the people, to be protected inviolate for the benefit of future generations. In addition, fourteen million acres in the national forests have been set aside as Wild and Wilderness Areas, where no roads may be built, seventeen and a half million acres are devoted to federal wildlife protection and management, and many millions of acres are protected as state parks and privately owned sanctuaries. This is a proud achievement, attained because the people as a whole recognize that the wisest use of these lands is the perpetuation of their aboriginal condition, as representative of the once vast wilderness that clothed the continent.

Although since colonial times a few voices had been crying that this wilderness was not inexhaustible, and that its resources were being ruthlessly diminished, it was not until the American Civil War that Abraham Lincoln officiated at the birth of American conservation, when he reserved what is now Yosemite National Park. During the following decades, the pattcrn of the robber barons was gradually superseded by the concept that the land and its resources were the common property of all of 